\title{
Anaphylactic Reactions in the Emergency Department of a Portuguese Tertiary Hospital: Clinical Characterization and Disease Notification
}

\author{
Reações Anafiláticas no Serviço de Urgência de um \\ Hospital Terciário Português: Caracterização Clínica e \\ Notificação
}

Ana Teresa FRÓIS $₫ 1$, Teresa CARDOSO²

Acta Med Port 2019 Feb;32(2):91-100 - https://doi.org/10.20344/amp.10820

ABSTRACT

Introduction: Anaphylaxis is significantly underdiagnosed, and the medical community's knowledge about it is precarious. The aim of this study is to characterize the patient population and the Emergency Department approach of anaphylaxis.

Material and Methods: Retrospective study of adult patients attending the Emergency Department of a tertiary care Portuguese hospital, over a year, with anaphylaxis. Data were obtained from each patient's clinical records and anonymized. A questionnaire evaluating knowledge about the notification of anaphylaxis was applied to Emergency Department physicians.

Results: The study included 69 patients. Cutaneous (97\%) and respiratory features (80\%) were most prevalent; $22 \%$ of patients presented with shock or related symptoms. There were no reported biphasic reactions or deaths. The likely allergen was identified in $73 \%$, most commonly food; $12 \%$ of reactions were related to a previously known allergen. Epinephrine was administered to $15 \%$. Referral to an Immunoallergologist was done in $36 \%$ of patients, and $10 \%$ received or already possessed an epinephrine autoinjector. Among six parameters recommended for auditing clinical practice, $70 \%$ of cases fulfilled less than half. Only $13 \%$ of physicians knew it was mandatory to register all cases in the Portuguese Catalogue of Allergies and Other Adverse Reactions, and only $4 \%$ knew how to do it; regarding notification to the National Authority of Medicines and Health Products results were slightly better.

Discussion: Many patients with anaphylaxis present to the Emergency Department every year, and their clinical approach is not in agreement with national guidelines.

Conclusion: An educational program to increase medical awareness of the national guidelines and mandatory notification of all anaphylactic reactions should be implemented.

Keywords: Anaphylaxis/epidemiology; Anaphylaxis/etiology; Emergency Service, Hospital

RESUMO

Introdução: A anafilaxia é significativamente subdiagnosticada e o conhecimento médico acerca da mesma é precário. Pretende-se caracterizar a população de doentes e a abordagem clínica da anafilaxia no Serviço de Urgência.

Material e Métodos: Estudo retrospetivo da população adulta que recorreu ao Serviço de Urgência de um hospital terciário português durante um ano, com anafilaxia. Os dados foram obtidos dos registos clínicos de cada paciente e anonimizados. Um questionário para avaliar conhecimentos sobre notificação de reações anafiláticas foi aplicado aos médicos do Serviço de Urgência.

Resultados: O estudo incluiu 69 doentes. Os sintomas cutâneos (97\%) e respiratórios (80\%) foram os mais prevalentes; $22 \%$ apresentaram-se com choque ou sintomas associados. Não se registaram reações bifásicas ou óbitos. O alergénio provável foi identificado em $73 \%$; maioritariamente foram alimentos; $12 \%$ das reações foram com um alergénio previamente conhecido. Adrenalina foi administrada em 15\%; 36\% foram encaminhados para Imunoalergologia; $10 \%$ receberam ou já possuíam adrenalina autoinjetável. Em $70 \%$ dos casos, menos de metade dos seis parâmetros das Normas de Orientação Clínica foram cumpridos. Apenas $13 \%$ dos médicos sabia que era obrigatório registar todos os casos no Catálogo Português de Alergias e Outras Reações Adversas e apenas $4 \%$ sabiam como fazê-lo; relativamente à notificação das reações a fármacos à Autoridade Nacional do Medicamento e Produtos de Saúde, I.P., obtiveram-se resultados ligeiramente melhores.

Discussão: Muitos doentes recorrem ao Serviço de Urgência com reações anafiláticas e a sua abordagem não está em concordância com as normas de orientação clínica nacionais.

Conclusão: É necessário implementar ações de formação relativamente à abordagem clínica e notificação da anafilaxia.

Palavras-chave: Anafilaxia/epidemiologia; Anafilaxia/etiologia; Serviço de Urgência Hospitalar

\section{INTRODUCTION}

Anaphylaxis is a serious allergic reaction that is rapid in onset and may cause death.

Anaphylaxis is a frequent situation and its incidence is rising. Two studies conducted in the same county of the United States of America (USA), the first between 1983 and 1987 and the second between 2001 and 2010, demonstrated a rise from 21 to 42 per 100000 person-years. ${ }^{2,3}$

Another USA study recorded a 101\% increase in Emergency Department (ED) visits due to anaphylaxis between 2005 and $2014 .{ }^{4}$ Despite this, both inpatient and overall mortality rates in the USA appear to have remained stable between 1999 and 2009, and well below 1 per million. ${ }^{5}$

Data regarding the incidence and prevalence of anaphylaxis in Portugal are scarce and dubious, since there is

1. Aluno de Mestrado Integrado em Medicina. Instituto de Ciências Biomédicas Abel Salazar. Universidade do Porto. Porto. Portugal.

2. Unidade de Cuidados Intensivos Polivalente. Hospital de Santo António. Centro Hospitalar Universitário do Porto. Porto. Portugal.

$\triangle$ Autor correspondente: Ana Teresa Fróis. atfrois@hotmail.com

Recebido: 20 de maio de 2018 - Aceite: 26 de outubro de 2018 | Copyright @ Ordem dos Médicos 2019 
a high level of underdiagnosis and under notification. The Health General Directorate, through the Clinical Standard no. $002 / 2012$ of $04 / 07 / 2012$ updated in 11/08/2015, required the registration of all allergy and adverse reaction cases, including anaphylaxis, in the Portuguese Catalogue of Allergies and Other Adverse Reactions (CPARA). ${ }^{6}$ Data registered between 2012 and 2013 demonstrates an incidence of anaphylaxis of 11.2 per 100000 . However, even though this estimate can serve as guidance, it probably underestimates the real incidence of the problem. ${ }^{7,8}$

In essence, any agent capable of activating mast cells or basophiles can cause an anaphylactic reaction. ${ }^{9}$ There seems to be a variation in the etiologic agents according to geographic distribution (Table 1).

According to worldwide epidemiology studies, anaphylaxis manifests mostly with mucocutaneous symptoms, associated with one or more symptoms from the respiratory, cardiovascular or digestive systems (Table 2).

The currently accepted clinical criteria for the diagnosis of anaphylaxis were first defined in the Second Symposium on the Definition and Management of Anaphylaxis by the National Institute of Allergy and Infectious Disease/Food Allergy and Anaphylaxis Network and later adopted by the World Allergy Organization (Table 3). ${ }^{1,10}$ These criteria were adopted by the Portuguese Health General Directorate, in 2012. ${ }^{11}$

Diagnosis is mainly based on clinical suspicion and confirmed by clinical examination. Laboratory tests can be helpful in establishing if the patient experienced an anaphylactic reaction. Marked increases in total tryptase are seen during an anaphylactic event, especially in subjects with anaphylaxis of sufficient severity to cause hypotension. ${ }^{12}$ The best time to measure serum tryptase is between 1 to 2 hours after the onset of symptoms, and no longer than 6 hours after. ${ }^{13}$ Portuguese guidelines recommend tryptase measurements in the initial management of anaphylaxis, ideally with three blood samples: 1) immediately after beginning treatment; 2) 1 - 2 hours after symptom onset; 3 ) upon discharge or during follow-up. ${ }^{11}$

The Portuguese guidelines for the initial evaluation and treatment approach of anaphylaxis are defined on Clinical Standard No. 014/2012 of 16/12/2012 updated in 18/12/2014, and summarized in Table $4 .{ }^{11}$ Also, all cases of adverse reactions to drugs, including anaphylactic reactions, should be notified to the National Authority of Medicines and Health Products, I.P. (INFARMED).

After the treatment of an anaphylactic reaction, all patients should remain in observation, since there may be either a recurrence of the reaction after the effect of epinephrine disappears or a biphasic reaction. ${ }^{1}$ Clinically important biphasic reactions are defined as recurrent or new signs or symptoms of anaphylaxis without obvious re-exposure to an allergen. ${ }^{14}$ Its incidence is highly variable, ranging between $0.4 \%$ and $18 \% .14,15$

There is a significant underdiagnosis of ED events fulfilling the diagnostic criteria for anaphylaxis, which are frequently misdiagnosed, for example, as a mild allergic reaction..$^{16}$ In a USA study, only $43 \%$ of events meeting anaphylaxis criteria were correctly diagnosed and reported in the clinical registries. ${ }^{17}$ Another American study determined

Table 1 - Incidence of different causative agents in epidemiologic studies

\begin{tabular}{|c|c|c|c|c|}
\hline Study & Food & Insect venom & Drugs & Others / Non identified \\
\hline $\begin{array}{l}\text { Lee et al, USA, } \\
2001-2010 \\
(n=631)^{3}\end{array}$ & $37.0 \%$ & $25.0 \%$ & $22.0 \%$ & $17.0 \%$ \\
\hline $\begin{array}{l}\text { Clark et al, USA, } \\
2001-2008 \\
(n=11.972)^{25}\end{array}$ & $19.6 \%$ & $8.3 \%$ & $5.7 \%$ & $66.4 \%$ \\
\hline $\begin{array}{l}\text { Smit et al, Hong Kong, } \\
1999-2003 \\
(n=282)^{26}\end{array}$ & $\begin{array}{c}44.3 \% \\
\text { Seafood: } 31.6 \%\end{array}$ & $6.4 \%$ & $\begin{array}{c}\qquad 36.2 \% \\
\text { NSAIDs: } 9.2 \% \\
\text { Antibiotics: } 8.5 \%\end{array}$ & $13.1 \%$ \\
\hline $\begin{array}{l}\text { Alangari, Saudi Arabia, } \\
2009-2012 \\
(n=39)^{27}\end{array}$ & $28.0 \%$ & $18.0 \%$ & $10.0 \%$ & $44.0 \%$ \\
\hline $\begin{array}{l}\text { Brown et al, Australia, } \\
1998-1999 \\
(n=142)^{24}\end{array}$ & $\begin{array}{l}17.0 \% \\
\text { Seafood: } 9.2 \% \\
\text { Nuts: } 2.8 \%\end{array}$ & $17.5 \%$ & $\begin{array}{l}\quad 28.0 \% \\
\text { Antibiotics: } 12.0 \% \\
\text { NSAIDs: } 7.0 \%\end{array}$ & $37.3 \%$ \\
\hline $\begin{array}{l}\text { CPARA, Portugal, } \\
2012-2013 \\
(n=1209)^{7,8}\end{array}$ & $\begin{array}{l}\quad 4.0 \% \\
\text { Seafood: } 1.3 \% \\
\text { Nuts: } 0.6 \% \\
\text { Dairy: } 0.2 \%\end{array}$ & $3.0 \%$ & $\begin{array}{c}87.0 \% \\
\text { Antibiotics: } 42.6 \% \\
\text { NSAIDs: } 16.7 \%\end{array}$ & $5.0 \%$ \\
\hline
\end{tabular}

CPARA: Portuguese Catalogue of Allergies and Other Adverse Reactions; NSAIDs: non-steroid anti-inflammatory drugs; USA: United States of America 


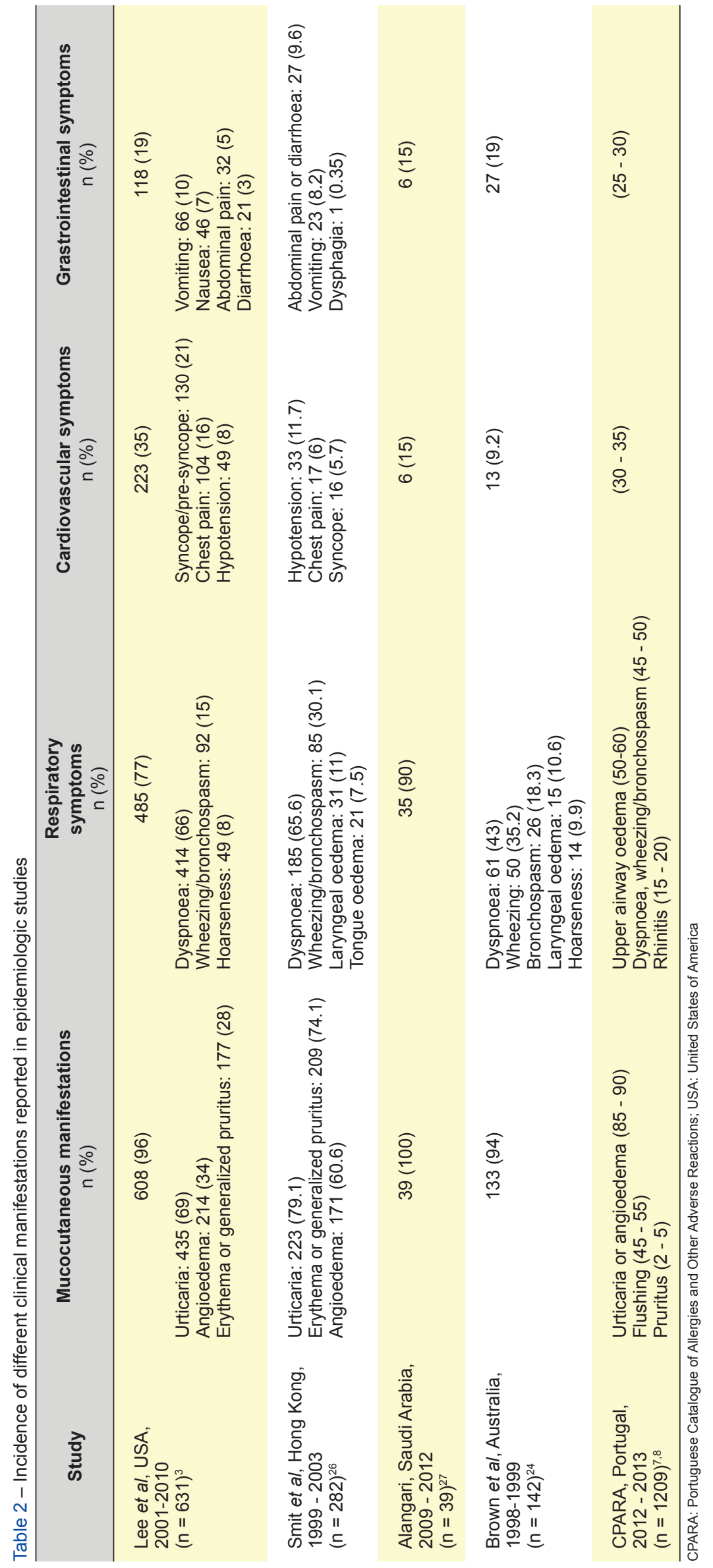

that only $53 \%$ of patients with food-related allergic reactions and $87 \%$ of patients with insect sting-related allergic reactions were correctly diagnosed with the 9th version of International Classification of Diseases (ICD-9). ${ }^{18}$ A possible reason for the under diagnosis of anaphylaxis may be the lack of knowledge by health professionals regarding this subject. A study conducted in France with medical residents determined that two thirds considered anaphylaxis approach throughout the medical degree insufficient and that anaphylaxis knowledge in the medical community was precarious. ${ }^{19}$

Considering the high importance of anaphylaxis and its ubiquity within clinical and surgical specialties, it is of utmost importance to approach this subject.

Globally, the aim of this study is to characterize the patient population and clinical approach of all anaphylactic reactions admitted to the ED of a tertiary care university hospital and specifically, to describe the patient population as well as the diagnostic and therapeutic approach of patients admitted to the ED with anaphylaxis, comparing collected data with national and international data, auditing the compliance with Clinical Standard No. 014/2012 of 16/12/2012 updated 18/12/2014 regarding the clinical approach of anaphylaxis, and determining the notification rate of anaphylaxis to CPARA and INFARMED.

\section{MATERIAL AND METHODS}

Ethical approval was obtained from the Ethical Committee for Health of Hospital de Santo António - Centro Hospitalar do Porto (HSA-CHP), in March 2018 - N/REF. 2017.224(193-DEFI/185-CES).

\section{Clinical characterization and approach}

This is a retrospective study, based on a consecutive series of adult patients ( $\geq 18$ years of age at the date of admission) diagnosed with anaphylaxis, admitted in the ED of HSA-CHP, between November $1^{\text {st }}, 2015$, and October $31^{\text {st }}$, 2016. The sample included all cases registered with discharge ICD-9 codes 995.0, 995.1, 995.2, 995.3, 995.6, 995.60, 995.61, 995.62, 995.63, 995.64, 995.65, 995.66, 995.67, 995.68, 995.69 and 995.7, who, after careful analysis of the clinical registries by the authors, were found to meet the currently accepted clinical criteria for the diagnosis of anaphylaxis (Table 3). The demographic and clinical data (sex, age, comorbidities, functional status, admission date, clinical presentation, severity grade, onset time, occurrence of biphasic 
Table 3 - Clinical criteria for the diagnosis of anaphylaxis ${ }^{1,11}$

Anaphylaxis is highly likely when any one of the following three criteria is fulfilled:

II

III

Acute onset of an illness (minutes to several hours) with involvement of the skin, mucosal tissue, or both (generalized urticaria, itching or flushing, swollen lips-tongue-uvula), and at least one of the following:

a) Respiratory compromise (dyspnoea, wheeze, bronchospasm, stridor, reduced PEF, hypoxemia) b) Reduced blood pressure or associated symptoms of end-organ dysfunction (hypotonia, syncope, incontinence)
Two or more of the following that occur rapidly after exposure to a likely allergen for that patient (minutes to several hours):

a) Involvement of the skin-mucosal tissue (generalized urticaria, itching or flushing, swollen lips-tongue-uvula)

b) Respiratory compromise (dyspnoea, wheeze, bronchospasm, stridor, reduced PEF, hypoxemia)

c) Reduced blood pressure or associated symptoms of end-organ dysfunction (hypotonia, syncope, incontinence) d) Gastrointestinal symptoms (crampy abdominal pain, vomiting)
Reduced blood pressure after exposure to known allergen for that patient (minutes to several hours):

- Infants and children: low systolic blood pressure (age-specific) or greater than $30 \%$ decrease in systolic blood pressure - Adults: systolic blood pressure of less than $90 \mathrm{mmHg}$ or greater than $30 \%$ decrease from that person's baseline

PEF: peak expiratory flow

Table 4 - Portuguese guidelines for the initial management of anaphylaxis ${ }^{11}$

Removing known or likely allergen

Evaluate

Airway (A), Breathing (B), Circulation (C), Disability (D), Exposure (E)

Call for help

Administer epinephrine aqueous solution 1:1000 IM

Dosing: adjusted to age group

- < 6 years: $0.15 \mathrm{mg}$

- 6 - 12 years: $0.3 \mathrm{mg}$

- > 12 years: $0.5 \mathrm{mg}$

Adjusted to weight: $0.01 \mathrm{mg} / \mathrm{kg} / \mathrm{dosing}$ (adults) or $0.3 \mathrm{mg}$ (children $<12$ years or $<40 \mathrm{~kg}$ )

Injection site: anterolateral side of mid-thigh

General measures

Position the patient according to signs and symptoms:

- loss of consciousness (breathing) or vomit: lateral decubitus

- hypotension or hypotonia: dorsal decubitus with elevation of the lower limbs (Trendelemburg)

- respiratory distress: semi-seated (position comfortable for the patient)

- pregnancy: left lateral decubitus

Administer supplementary oxygen $\left(\mathrm{O}_{2}, 10-15 \mathrm{~L} / \mathrm{min} ; \mathrm{FiO}_{2} \sim 40 \%-80 \%\right)$

Monitor the patient (heart rate, blood pressure, respiratory rate, oxygen saturation)

Consider placement of peripheral venous access

Consider blood sample for tryptase (ideally 3 samples: $1^{\text {st }}-$ immediately after beginning treatment; $2^{\text {nd }}-1$ to 2 hours after the beginning of the symptoms; $3^{\text {rd }}$ - upon discharge or during follow-up)

IM: intramuscular; $\mathrm{O}_{2}$ : oxygen; $\mathrm{FiO}_{2}$ : fraction of inspired oxygen

reaction, likely allergen, treatment, hospitalization time, outcome, follow-up) were obtained from the clinical records of each patient and registered anonymously in the database. The comorbidities were determined using the Charlson comorbidity index $(\mathrm{CCl}) .^{20}$ Functional status was determined with the Karnofsky scale. ${ }^{21}$ The severity of anaphylactic reactions was classified using Ring and Messmer severity scale. ${ }^{22}$

To audit the compliance with Clinical Standard No. $014 / 2012$ of $16 / 12 / 2012$ updated $18 / 12 / 2014$, the audit instrument available in the same document was used.11

\section{Case notification}

Data regarding CPARA and INFARMED notifications and compliance with the Clinical Standard were requested from the Quality, Risk, Hygiene, Health and Safety Management Department of HSA-CHP, the Ministry of Health Shared Services, and INFARMED.

A questionnaire evaluating medical knowledge about notification of anaphylaxis cases to CPARA and INFARMED was applied to ED physicians that attend patients triaged to Internal Medicine or General Practice / Family Medicine physicians. This included: all HSA-CHP physicians from the Internal Medicine Department, who have weekly shifts in the ED; General Practice / Family Medicine physicians hired by HSA-CHP to work exclusively in the ED; physicians hired from an external company who work shifts in Internal Medicine or General Practice / Family Medicine in 
the ED; and physicians that work in the Emergency Room (attend patients who are given red Manchester triage colour at admission). Questionnaires were distributed and collected within a period of a week (between April $9^{\text {th }}$ and $15^{\text {th }}$, 2018) to all above mentioned HSA-CHP ED physicians.

\section{Statistical analysis}

Categorical variables are described as absolute frequencies $(n)$ and relative frequencies (\%). For continuous variables, median, percentiles minimum and maximum or mean and standard deviation (SD) are used, regarding the distribution. Comparisons between categorical variables are made using Chi-Square and Fisher exact test. For continuous variables, Mann-Whitney test and Kruskal-Wallis test are used. The significance level used is 0.05 . Statistical analysis was performed using the software Statistical Package for the Social Sciences v. 24.0.

\section{RESULTS}

\section{Clinical characterization and approach}

Medical records of 972 patients satisfying the elligible discharge ICD-9 codes were analysed; 69 patients met the criteria for anaphylaxis. Reasons for exclusion included the presence of only mucocutaneous symptoms, respiratory symptoms, or gastrointestinal symptoms, exposure to a known allergen without clinical symptoms, intra-hospital anaphylactic reactions, or other conditions mistakenly coded as allergic reactions. The mean age was 43.7 years (SD 18.4; range: 19 - 88 years). Females accounted for $60.9 \%$ of patients.

Based on the $\mathrm{CCl}$ score, $43.5 \%$ of patients had no comorbidities, $40.6 \%$ were categorized as mild $(\mathrm{CCl}$ scores of $1-2$ ), and $11.5 \%$ were categorized as both moderate or severe ( $\mathrm{CCl}$ scores of 3 - 4 and $\geq 5$, respectively). Regarding the Karnofsky performance scale, prior to this acute episode, $79.7 \%$ of patients had no evidence of disease, $15.9 \%$ were able to carry on normal activity with minor signs or symptoms of disease, and $2.9 \%$ required assistance and frequent medical care.

The clinical features of the 69 patients studied are presented in Table 5. Overall, mucocutaneous symptoms were the most prevalent, followed by respiratory, cardiovascular, and gastrointestinal features. Using the Ring and Messmer severity scale, 54 patients $(78.3 \%)$ presented with grade II (measurable, but not life-threatening cardiovascular, gastrointestinal or respiratory disturbances), and 15 patients $(21.7 \%)$ presented with grade III (shock or related symptoms). There were no recorded deaths in this study. The median onset time was 30 minutes $[(I Q R)=30(0-60)]$. In 43 patients $(62.3 \%)$, no data regarding onset time was available in the registries. None of the 69 patients developed a biphasic reaction. There was no statistically significant association of patients' previous characteristics (age, gender, functional status or comorbidities) with the severity of the anaphylactic reaction (Table 6).

The likely causative agents found in this study are presented in Table 5. The most common category was food, followed by drugs, and lastly by insects. Causative foods mainly included fish and seafood. Drugs included antibiotics and nonsteroidal anti-inflammatory agents in most cases. Insects included bee and Asian wasp stings. No cause was apparent in $27.5 \%$ of patients. Of the studied patients, $44.9 \%$ had previously identified allergies, and,

Table 5 - Clinical features and likely causative agents of the 69 patients with anaphylaxis, $\mathrm{n}(\%)$

\begin{tabular}{|c|c|}
\hline \multicolumn{2}{|c|}{ Clinical features } \\
\hline Mucocutaneous manifestations & $67(97.1)$ \\
\hline Angioedema & $45(65.2)$ \\
\hline Erythema & $38(55.1)$ \\
\hline Pruritus & $25(36.2)$ \\
\hline Urticaria & $22(31.9)$ \\
\hline Respiratory symptoms & $55(79.7)$ \\
\hline Dyspnoea & $47(68.1)$ \\
\hline Laryngeal oedema & $11(15.9)$ \\
\hline Wheezing/bronchospasm & $10(14.5)$ \\
\hline Hoarseness & $3(4.3)$ \\
\hline Cough & $2(2.9)$ \\
\hline Cardiovascular symptoms & $27(39.1)$ \\
\hline Hypotension & $14(20.3)$ \\
\hline Syncope & $8(11.6)$ \\
\hline Chest Pain & $6(8.7)$ \\
\hline Peripheral hypoperfusion & $3(4.3)$ \\
\hline Gastrointestinal symptoms & $21(30.4)$ \\
\hline Nausea & $10(14.5)$ \\
\hline Vomiting & $8(11.6)$ \\
\hline Abdominal pain & $6(8.7)$ \\
\hline Dysphagia & $4(5.8)$ \\
\hline Diarrhoea & $3(4.3)$ \\
\hline Other symptoms & $7(10.1)$ \\
\hline \multicolumn{2}{|c|}{ Likely allergen } \\
\hline Food & $24(34.8)$ \\
\hline Fish/seafood & $14(20.3)$ \\
\hline Nuts & $1(1.4)$ \\
\hline Fruits & $1(1.4)$ \\
\hline Chocolate & $1(1.4)$ \\
\hline Drugs & $21(30.4)$ \\
\hline Antibiotics & $8(11.6)$ \\
\hline NSAIDs & $5(7.2)$ \\
\hline Opioid analgesics & $2(2.9)$ \\
\hline IV contrast & $2(2.9)$ \\
\hline Insect venom & $3(4.3)$ \\
\hline Bee sting & $2(2.9)$ \\
\hline Asian wasp sting & $1(1.4)$ \\
\hline Others & $2(2.9)$ \\
\hline Non identified & $19(27.5)$ \\
\hline
\end{tabular}

IV: intravenous; NSAIDs: non-steroid anti-inflammatory drug 
Table 6 - Patients' and anaphylactic reaction characteristics, according to the grades of severity of anaphylaxis

\begin{tabular}{|c|c|c|c|}
\hline Variable & Ring and Messmer grade II & Ring and Messmer grade III & $p$ value \\
\hline Age, mean \pm SD & $42 \pm 18$ & $49 \pm 19$ & $0.210^{\#}$ \\
\hline Female gender, n (\%) & $33(61)$ & $9(60)$ & 1.000 \\
\hline Karnofsky $\geq 70, \mathrm{n}(\%)$ & $52(96)$ & $15(100)$ & $1.000^{*}$ \\
\hline No comorbidities, n (\%) & $27(50)$ & $3(20)$ & $0.126^{*}$ \\
\hline Previous allergies, $\mathrm{n}(\%)$ & $27(50)$ & $4(27)$ & $0.146^{*}$ \\
\hline Mucocutaneous symptoms, $\mathrm{n}(\%)$ & $54(100)$ & $13(87)$ & $0.045^{*}$ \\
\hline Respiratory symptoms, n (\%) & $44(82)$ & $11(73)$ & $0.485^{*}$ \\
\hline Cardiovascular symptoms, $\mathrm{n}(\%)$ & $20(37)$ & $7(47)$ & 0.558 \\
\hline Gastrointestinal symptoms, n (\%) & $17(32)$ & $4(27)$ & $1.000^{*}$ \\
\hline $\begin{array}{l}\text { Likely allergen, n (\%) } \\
\text { Food } \\
\text { Drugs } \\
\text { Insects } \\
\text { Others } \\
\text { Unknown }\end{array}$ & $\begin{array}{r}21(39) \\
13(24) \\
3(6) \\
2(4) \\
15(28)\end{array}$ & $\begin{array}{r}3(20) \\
8(53) \\
0(0) \\
0(0) \\
4(27)\end{array}$ & $0.267^{*}$ \\
\hline
\end{tabular}

*: Fisher exact test; ": Mann-Whitney test

of these, $25.8 \%$ had the present reaction with a previously known allergen.

Of the 69 patients admitted with anaphylaxis, $22(31.9 \%)$ received yellow, $44(63.8 \%)$ orange, and 3 (4.3\%) red Manchester triage colour at hospital admission. Overall, the median time from triage to first medical contact was 15 minutes $[(I Q R)=15(9-31)]$. The median time between triage to first medical contact was shorter for patients whose Manchester triage colour was more emergent, with median (IQR): 29 (16 - 76) for yellow, 11 (7 - 20) for orange and $12(2-38)$ for red $(p=0.001)$.

Overall, only four patients $(5.8 \%)$ had blood collected for tryptase measurements. In these patients, only one sample was collected, and median time until sample collection was 14 minutes $[(I Q R)=14(4-42)]$. Regarding administered medications, 63 patients $(91.3 \%)$ received corticosteroids, $59(85.5 \%) \mathrm{H} 1$-antihistamines, 15 (21.7\%) H2-antihistamines, and $10(14.5 \%)$ epinephrine. Of the latter, one patient self-administered an epinephrine auto-injector, four patients received epinephrine from the pre-hospital emergency team, and five patients received epinephrine at the ED. Epinephrine was administered intravenously in one patient, subcutaneously in two patients, and intramuscularly in the other 7 cases. The median time between first medical contact and epinephrine administration was 59 minutes [(IQR) = $59(15-82)$ ]. Median surveillance time after epinephrine administration was 369 minutes [(IQR) = $369(214-426)]$. Other therapies included intravenous fluids in $18(26.1 \%)$, bronchodilators in $8(11.6 \%)$, proton pump inhibitors or antiemetics in 9 (13\%), and benzodiazepines in 4 (5.8\%) patients.

In the 69 patients with anaphylaxis, median hospital stay before discharge was 239 minutes [(IQR) = $239(168-385)$ ], with 67 patients $(97.1 \%)$ discharged directly from the ED after the monitoring period, $1(1.4 \%)$ admitted to the ED observation ward, and $1(1.4 \%)$ admitted to the Intensive Care Unit. Upon discharge, 25 patients $(36.2 \%)$ were referred to an Immunoallergology outpatient clinical appointment, and $16(23.2 \%)$ were referred to their local general practitioner / family physician. Seven patients $(10.1 \%)$ received or were confirmed to already possess an epinephrine autoinjector. Upon discharge, the most frequently attributed ICD-9 codes were: 995.3 Allergy, unspecified - 56 (81.2\%); 995.1 Angioneurotic oedema - 5 (7.2\%); 995.65 Anaphylactic shock due to fish - three $(4.3 \%)$; 995.0 Other anaphylactic shock - three (4.3\%).

\section{Case notification}

Upon contact with the Quality, Risk, Hygiene, Health and Safety Management Department of HSA-CHP, there were no registered cases of anaphylaxis reported within the studied period. While contacting the Ministry of Health Shared Services, it was ascertained that no registered clinical data was submitted to CPARA from HSA-CHP in this period. INFARMED provided a list of all cases of allergic reactions reported from HSA-CHP within the studied time frame and none of the cases from our study were reported to INFARMED.

\section{Compliance with clinical standard}

Using the parameters considered for the evaluation of compliance with Clinical Standard No. 014/2012 of $16 / 12 / 2012$ updated $1 / 12 / 2014$, the most achieved parameter was detailing in the clinical registry signs and symptoms referring to two or more systems (94.2\%), followed by evidence that the known or likely allergen was removed $(42.0 \%)$, and by making sure that, after the episode, the patient is referred to observation by an Immunoallergology specialist for confirmation of diagnosis and management $(36.2 \%)$. Parameters with lower rates of achievement were maintaining the patient in observation for at least 8 to 24 hours after clinical stability was achieved (17.3\%), early administration of intramuscular epinephrine $(8.7 \%)$, and registering all cases in CPARA $(0 \%)$. No cases $(0 \%)$ had all 
six or five out of six parameters achieved; six cases $(8.7 \%)$ had four out of six parameters achieved; 15 cases $(21.7 \%)$ achieved three parameters; 24 cases (34.8\%) achieved two parameters; 22 cases (31.9\%) achieved one parameter; and two cases $(2.9 \%)$ did not achieve any parameter.

\section{Medical knowledge}

In this study, 117 physicians met the inclusion criteria and $75(64.1 \%)$ returned the filled questionnaire. One form had incomplete data.

Of all respondents, 18 (24.0\%) were physicians hired from an external company or directly by HSA-CHP to work exclusively in the ED, 29 (38.7\%) HSA-CHP physicians from the Internal Medicine Department, and 28 (37.3\%) physicians that work in the Emergency Room. Overall, 30 physicians (40.0\%) were Internal Medicine specialists, 15 $(20.0 \%)$ were specialists in another medical specialty, which included, in alphabetical order, Endocrinology, Gastroenterology, Infectious Diseases, Intensive Care, Nephrology and Oncology, 15 (20.0\%) in Anaesthesiology, 14 (18.7\%) in General Practice / Family Medicine, and $1(1.3 \%)$ in Surgery. Of these, $44(58.7 \%)$ were residents, 13 (17.3\%) were consultants, and 7 (9.3\%) were senior consultants. In the previous year, 44 physicians $(58.7 \%)$ had contact with a suspected or proven anaphylactic reaction in an emergency setting.

Only $15(20.0 \%)$ physicians confirmed that they were aware of the CPARA platform's existence. Of these, three heard about it in this hospital, four heard about it in another hospital, one on the Internet, one in a congress and one in a Health Centre; the remaining 5 did not know where they heard about it. Of all physicians, only 10 (13.3\%) knew it was mandatory to register all allergy and anaphylaxis cases in CPARA, and only three $(4.0 \%)$ knew how to make the registration. Only two physicians $(2.7 \%)$ reported having registered a case in CPARA before and it was not on this ED. Of the 13 physicians who have heard about CPARA but never reported a case in the platform, five (38.5\%) did not have contact with a suspected or proven case of anaphylaxis in the previous year; five (38.5\%) did not know that the registry was mandatory, and $12(92.3 \%)$ did not know how to make the notification.

Regarding knowledge of INFARMED notifications, 59 $(79.7 \%)$ physicians were aware of the need to register allergic and anaphylactic reactions to drugs to INFARMED, 26 $(35.1 \%)$ knew how to make that notification, and 14 (18.9\%) had done at least one. Of the 60 physicians who never made a notification to INFARMED, 48 (80.0\%) reported not knowing how to do it.

All physicians in this study agreed that more training was needed regarding this subject. Regarding the ways to provide physicians with the necessary information and increase notification rates, $74.3 \%$ elected as the preferred method creating a direct link for notifications within the hospital access platform, $59.5 \%$ training initiatives, $51.4 \%$ information by e-mail, $48.6 \%$ information posters within the ED, $44.6 \%$ information by SMS, $35.1 \%$ providing information within the hospital intranet, and $17.6 \%$ chose distribution of flyers with selected information.

\section{DISCUSSION}

From the initial sample of 972 cases fulfilling the ICD-9 codes selected, only $69(7 \%)$ patients met the clinical criteria for anaphylaxis. This is mainly due to the fact that a specific code for anaphylaxis is missing in the ICD-9 classification. ICD-9 codes either consider "allergy" or "anaphylactic shock", which leaves out the rest of the spectre of anaphylactic reactions. For this reason, physicians have difficulty in attributing a specific ICD-9 code for an anaphylaxis event, and reactions such as mild allergic reaction are attributed the same code as an anaphylactic reaction. This issue persisted in the 10th version of International Classification of Diseases (ICD-10) but is being addressed in the forthcoming 11th version of International Classification of Diseases (ICD-11), with the ellaboration of a "Allergic and hypersensitivity conditions" section within the chapter "Disorders of the Immune System". This section will be divided in 8 subsections, including allergic or hypersensitivity disorders involving the respiratory tract, the eye, skin and mucous membranes, the gastrointestinal tract and of unspecified nature, complex allergic or hypersensitivity reactions and anaphylaxis. ${ }^{23}$ The authors believe this will be a major improvement from the ICD-10 classification and will hopefully resolve present issues with anaphylaxis classification, with the end result of improving future audits and quality of care.

The mean age of patients included in the study was 43,7 years, which is in agreement with previous studies, that reported mean ages between 32 and 52 years, and lower than previous Portuguese reports (51.8 years). ${ }^{7,8}$ Females outnumbered males by a ratio of $3: 2$, which is similar to data reported by Brown et $a^{24}$ in Australia, Clark et $a^{25}$ and Motosue et $a^{4}$ in the USA, but contrary to data reported by Smit et $a^{26}$ in Hong Kong or Alangari ${ }^{27}$ in Saudi Arabia, which had males outnumbering women by a ratio of 3:2.

Like other studies, mucocutaneous manifestations were the most prevalent, followed by respiratory symptoms. Mucocutaneous manifestations were not present in all patients, but patients with acute anaphylaxis may present without mucocutaneous features for many reasons, including treatment before hospital admission, the rapid onset of airway oedema or circulatory shock, or the spontaneous resolution of cutaneous signs. Regarding severity, our $21.7 \%$ incidence of severe life-threatening reactions is similar to the incidence reported by Clark et $a^{25}$ in the USA (22\%), but lower than that reported by Brown et $a^{24}$ in Australia $(42.25 \%)$. However, the severity criteria used in these studies were different, which may in part justify the differences found in the prevalence of severity grades.

Biphasic reactions can be rare, and none of our patients presented with one. There were no deaths in this study, like in many previous studies in Portugal and other countries. This may reflect an adequate and efficient approach of these situations on an emergency setting. 
Food was the main class of allergens in our study $(34.8 \%)$, and had a minor representation in CPARA $(4 \%))^{7,8}$ Drug hypersensitivity reactions had an important role in our study, but less than in CPARA $(30.4 \%$ vs $87 \%))^{7,8}$ As expected, in Portugal insect venom remains a minor cause $(4.3 \% \text { in our study vs } 3 \% \text { in CPARA) })^{7,8}$ No cause was apparent in $30.4 \%$ of our cases, which is similar to rates reported by Brown et $a^{24}(27 \%)$, lower than rates reported by Clark et $a^{25}(66 \%)$ or Alangari27 $(44 \%)$, but higher than in $\mathrm{CPARA}^{7,8}(5 \%)$. A pre-existing allergy to the etiologic agent was known in $11.6 \%$ of cases, two cases with insect stings and six cases with food. Regarding food allergies, a better explanation or reinforcement to the patient about the importance of avoiding the allergen is beneficial to prevent subsequent cases. Of notice is the fact that none of the cases of anaphylaxis to a previously known allergen were iatrogenic, which might reflect a good compliance of the medical community in researching the information concerning allergies to avoid prescription of previously identified allergy-inducing medications.

Regarding the patient approach, there was a significant lack of compliance with national guidelines. Despite the existence of a clear national recommendation for tryptase measurement in anaphylaxis ${ }^{11}$, tryptase blood samples were collected in a minority (5.8\%) of cases, and only one sample was collected, ranging between three and 48 minutes after admission. The correct use of the tryptase test could be improved with the generation of a tryptase measurement option within the diagnostic tests, which would prescribe automatically the three samples needed, and the nursing staff would receive information about all correct blood collecting times.

With intramuscular epinephrine being considered standard of care for all patients with anaphylaxis, it is disconcerting that only $10.1 \%$ of patients received early intramuscular administration of the drug, either pre- or intra-hospital. As the initial approach is similar in all cases of anaphylaxis, information regarding management guidelines (Table 4) could be available at all ED or easily accessible on the computer programme for consultation when needed. Other medications administered were mainly corticosteroids (91.3\%), within similar rates reported by Smit et $a^{26}(91.5 \%)$, and higher than those reported by Brown et $a^{24}(74.5 \%)$ or Lee et $\mathrm{a}^{\beta}(64 \%)$. The use of $\mathrm{H} 1$-antihistamines is in the range of previous reported values $(85.5 \%$ vs $72 \%-94.5 \%)$, and the same was observed for $\mathrm{H} 2$-antihistamines $(21.7 \%$ vs $1.42 \%$ - 60.5\%).

Despite there being no cases of biphasic allergic reactions in our study, its occurrence is well described in the literature, and patients should remain in observation for 8 to 24 hours, which was only achieved in $17.3 \%$ of cases. The proportion of patients discharged directly from the ED was higher in our study $(97.10 \%)$, than in Lee et $a^{\beta}(74 \%)$, Brown et $a^{24}(33 \%)$, or Smit, et $a^{26}(1.4 \%)$. This may reflect the lack of monitoring time after stabilization, as the percentage of patients admitted to the ED observation ward $(1.4 \%)$ was drastically lower than in the other studies, including Brown et $a^{24}(61 \%)$, or Smit et $a^{26}$ (54.6\%). This can be due to external determinants, such as the bed availability, but can be increased if a clear protocol recommends monitoring time, so that economic or political factors do not override good clinical practice.

Although $10.1 \%$ of our patients received or already possessed an epinephrine autoinjector, which is higher than rates reported by Brown et $a^{24}(5.3 \%)$, it is lower than desirable. Only $36.2 \%$ of patients were referred to an Immunoallergology outpatient clinic, and $23.2 \%$ were referred to their local general practitioner / family physician, which is higher than reported by Brown, et al. ${ }^{24}$ (23\% and $10 \%$, respectively), but still lower than acceptable. This rate of referral could be increased if, for example, when discharging a patient with a diagnostic code of anaphylaxis, an alert message box requiring scheduling an appointment would appear on the computer programme.

Considering that, in Portugal, it is mandatory to report all allergic and anaphylactic reactions to CPARA, it is appalling that only $20 \%$ of physicians in this tertiary care university hospital were aware of the platform's existence. Since none of the 69 anaphylactic cases studied was notified, we can presume that this might be due to a lack of knowledge regarding the obligation to report these cases and how to do it, which was confirmed by the survey done. Results were substantially better concerning knowledge of the need to notify reactions to drugs to INFARMED.

Most importantly, the quality of clinical registries requires improvement to make sure all relevant information is documented, and this need cannot be stressed enough within the medical community.

Taking into consideration the data found in this study, the authors think it could be of great benefit for the Portuguese medical community the future development of a national study evaluating physician's knowledge about anaphylaxis diagnosis and treatment.

This is an ongoing concern of the Sociedade Portuguesa de Alergologia e Imunologia Clínica (SPAIC) that prompted the release, in 2018 , of a clinical poster on the diagnosis and treatment of anaphylaxis, to be disseminated throughout the acute clinical setting. ${ }^{28}$

\section{Limitations}

Data regarding clinical cases in this study were collected retrospectively, and it is likely that some cases may have been excluded by the discharge ICD- 9 codes chosen, and that some information in clinical registries may be incorrect or missing. There is no information regarding the possibility of the patient developing a biphasic reaction after discharge and going to another ED. Due to the method of choosing patients for this study, the incidence of anaphylaxis could not be determined. The fact that the patient reports contact with a specific allergen does not imply that it was the precipitant of the anaphylactic reaction, and so all allergens mentioned in this study are likely allergens. A consultation of the registry of a subsequent Immunoallergology appointment could provide more reliable data of this causative 
relation. Immunoallergology clinical referral rates in our series were low; in referred cases, it would be important to confirm that the patient attended the consultation and how long it was after the ED discharge.

The sample of surveyed physicians was obtained from those working in the ED at the time of this study (March and April 2018), which was not the same period as the clinical cases included in the study. The answers reported by these physicians may or may not be representative of the knowledge of the physicians that, during 2015 and 2016, worked in this ED and were responsible for the approach and notification of the studied cases.

\section{CONCLUSION}

Data obtained from this study suggests that more knowledge regarding the National Clinical Standard for clinical management of anaphylaxis in Portugal is needed, with particular emphasis on detailed clinical records, epinephrine administration, tryptase measurement, Immunoallergology referral and CPARA notification. This can be improved through a pre-designed template for clinical registry, that includes a link to generate a tryptase measurement request with the three samples needed, and the nursing staff would receive information about all correct blood collecting hours; when discharging a patient with a diagnostic code of anaphylaxis or allergic reaction, an alert message box requiring scheduling an appointment for a Immunoallergology specialist would appear on the computer programme auto-

\section{REFERENCES}

1. Sampson HA, Muñoz-Furlong A, Campbell RL, Adkinson NF Jr, Bock SA, Branum A, et al. Second symposium on the definition and management of anaphylaxis: summary report - second National Institute of Allergy and Infectious Disease/Food Allergy and Anaphylaxis network symposium. Ann Emerg Med. 2006;47:373-80.

2. Yocum MW, Butterfield JH, Klein JS, Volchek GW, Schroeder DR, Silverstein MD. Epidemiology of anaphylaxis in Olmsted county: a population-based study. J Allergy Clin Immunol. 1999;104:452-6.

3. Lee S, Hess EP, Lohse C, Gilani W, Chamberlain AM, Campbell RL. Trends, characteristics, and incidence of anaphylaxis in 2001-2010: a population-based study. J Allergy Clin Immunol. 2017;139:182-8.

4. Motosue MS, Bellolio MF, Van Houten HK, Shah ND, Campbell RL. Increasing emergency department visits for anaphylaxis, 2005-2014. J Allergy Clin Immunol Pract. 2017;5:171-5.

5. Ma L, Danoff TM, Borish L. Case fatality and population mortality associated with anaphylaxis in the United States. J Allergy Clin Immunol. 2014;133:1075-83.

6. Direção-Geral da Saúde. Norma n 002/2012 de 04/07/2012 atualizada a 11/08/2015 - Registo de Alergias e Outras Reações Adversas. 2015. [acedido 2018 abr 20]. Disponível em: https://www.dgs.pt/directrizes-dadgs/normas-e-circulares-normativas/norma-n-0022012-de-04072012. aspx.

7. Mota I, Pereira AM, Pereira C, Tomaz E, Ferreira MB, Sabino F, et al. Abordagem e registo da anafilaxia em Portugal. Acta Med Port. 2015;28:786-96

8. Amaral R, Morais-Almeida M, Gaspar A, Sá-Sousa A, Martins H, Fonseca J. A anafilaxia em Portugal: primeiros registos do Catálogo Português de Alergias e outras Reacções Adversas. Rev Port Imunoalergol. 2014;22:23-32.

9. Kemp SF, Lockey RF. Anaphylaxis: a review of causes and mechanisms. J Allergy Clin Immunol. 2002;110:341-8.

10. Simons FE, Ardusso LR, Bilò MB, El-Gamal YM, Ledford DK, Ring J, et al. World Allergy Organization Guidelines for the Assessment and Management of Anaphylaxis. World Allergy Organ J. 2011;4:13-37.

11. Direção-Geral da Saúde. Norma nº 014/2012 de 16/12/2012 atualizada matically as well as a direct link in the Emergency Department IT system, requiring the physician to report the case to CPARA and, in the event of a reaction to a medication, to INFARMED.

These recommendations could be summarized and distributed by posters or flyers in the Emergency Department, on the hospital intranet, by e-mail, by SMS or through practical training initiatives, to increase compliance and improve patients' prognoses. The authors also recommend the use of the SPAIC poster.

\section{PROTECTION OF HUMAN AND ANIMAL SUBJECTS}

The authors declare that the research procedures were performed according to the regulations of the institution's ethics committee and the Code of Ethics of the World Medical Association (Declaration of Helsinki).

\section{CONFIDENTIALITY OF DATA}

The authors declare that they have followed the protocols of their work centre regarding the publication of data from patients.

\section{CONFLICT OF INTEREST}

No conflict of interest has been declared by any author.

\section{FUNDING}

No financial support was received by any author.

a 18/12/2014 - Anafilaxia: abordagem clínica. 2014. [acedido 2018 abr 20]. Disponível em: https://www.dgs.pt/directrizes-da-dgs/normas-ecirculares-normativas/norma-n-0142012-de-16122012.aspx.

12. Schwartz LB. Diagnostic value of tryptase in anaphylaxis and mastocytosis. Immunol Allergy Clin North Am. 2006;26:451-63.

13. Laroche D, Vergnaud MC, Sillard B, Soufarapis $H$, Bricard $H$. Biochemical markers of anaphylactoid reactions to drugs - comparison of plasma histamine and tryptase. Anesthesiology. 1991;75:945-9.

14. Grunau BE, Li J, Yi TW, Stenstrom R, Grafstein E, Wiens MO, et al. Incidence of clinically important biphasic reactions in emergency department patients with allergic reactions or anaphylaxis. Ann Emerg Med. 2014;63:736-44.

15. Brazil E, MacNamara AF. "Not so immediate" hypersensitivity - the danger of biphasic anaphylactic reactions. J Accid Emerg Med. 1998;15:252-3.

16. Sclar DA, Lieberman PL. Anaphylaxis: underdiagnosed, underreported, and undertreated. Am J Med. 2014;127:S1-5.

17. Ross MP, Ferguson M, Street D, Klontz K, Schroeder T, Luccioli S Analysis of food-allergic and anaphylactic events in the National Electronic Injury Surveillance System. J Allergy Clin Immunol. 2008;121:166-71.

18. Clark S, Gaeta TJ, Kamarthi GS, Camargo CA. ICD-9-CM Coding of Emergency Department Visits for Food and Insect Sting Allergy. Ann Epidemiol. 2006;16:696-700.

19. Klein R, Lefevre S. Étude du savoir déclaratif des étudiants en médecine générale d'Alsace et de Lorraine à propos de l'anaphylaxie. Rev $\mathrm{Fr}$ Allergol. 2017;57:292-7.

20. Charlson ME, Pompei P, Ales KL, MacKenzie CR. A new method of classifying prognostic comorbidity in longitudinal studies: development and validation. J Chronic Dis. 1987;40:373-83.

21. Karnofsky D, Burchenal J. The clinical evaluation of chemotherapeutic agents in cancer. In: MacLeod C, editor. Evaluation of chemotherapeutic agents. New York: Columbia University Press; 1949. p.191-205.

22. Ring J, Messmer K. Incidence and severity of anaphylactoid reactions to colloid volume substitutes. Lancet. 1977;1:466-9. 
23. Tanno LK, Chalmers RJ, Calderon MA, Aymé S, Demoly P. Reaching multidisciplinary consensus on classification of anaphylaxis for the eleventh revision of the World Health Organization's (WHO) International Classification of Diseases (ICD-11). Orphanet J Rare Dis. 2017;12:53.

24. Brown AF, McKinnon D, Chu K. Emergency department anaphylaxis: a review of 142 patients in a single year. J Allergy Clin Immunol. 2001;108:861-6.

25. Clark S, Wei W, Rudders SA, Camargo CA. Risk factors for severe anaphylaxis in patients receiving anaphylaxis treatment in US emergency departments and hospitals. J Allergy Clin Immunol. 2014;134:1125-30.

26. Smit DV, Cameron PA, Rainer TH. Anaphylaxis presentations to an emergency department in Hong Kong: incidence and predictors of biphasic reactions. J Emerg Med. 2005;28:381-8.

27. Alangari $A A$. Characteristics of patients presenting to the emergency department with anaphylaxis in Riyadh, Saudi Arabia. J Taibah Univ Sci. 2014;9:318-21.

28. Carneiro-Leão L, Santos N, Gaspar A. Anaphylaxis, diagnosis and treatment [Letter to the editor]. Acta Med Port. 2018;31:134-8. 